\title{
DINAMIKA PSIKOSOSIAL REMAJA KORBAN KEKERASAN SEKSUAL
}

\author{
Sri Indaryani \\ Program Pascasarjana IImu Sosial Universitas Brawijaya \\ enyjoe816@gmail.com
}

\begin{abstract}
Abstrak
Merujuk pada judul penelitian lebih ditekankan pada kekerasan seksual kategori perkosaan, dalam Kamus Besar Bahasa Indonesia (1988) merupakan perbuatan pelanggaran dengan kekerasan.Perbuatan ini dilakukan dengan menggunakan paksaan, ancaman, suap, tipuan bahkan tekanan (Noviana, 2015).Penelitian ini bertujuan untuk mengungkap makna informatif yang terkandung dalam pikiran dan benak remaja yang mengalami kekerasan seksual.Metode yang dipakai kualitatif dengan pendekatan fenomenologi persepsi Ponty menitikberatkan pada wawancara tidak terstruktur dengan subjek penelitian adalah remaja korban kekerasan seksual. Data yang diperoleh melalui wawancara ataupun observasi akan berupa kata-kata, perilaku ataupun dokumentasi yang kesemuanya bersifat informantif dari pemahaman masing-masing individu korban kekerasan seksual sebagaimana pengalaman hidupnya dan bagaimana individu memberikan makna pada kejadian tersebut.

Hasil penelitian menunjukkan pemaknaan tubuh yang berbeda pada korban dengan latar belakang keluarga (nuclear family) berbeda. Refleksi dari Ponty tentang pemaknaan tubuh antara teori dan temuan, signifikan. Sebelum peristiwa kekerasan seksual terjadi semua korban menganggap bahwa tubuh mereka sangat penting dan harus dijaga. Setelah peristiwa kekerasan seksual dengan proses berbeda maka masing-masing korban dalam memaknai tubuhnya mengalami perbedaan.
\end{abstract}

Kata Kunci : Dinamika psikososial, kekerasan seksual anak, pemaknaan tubuh

\begin{abstract}
Referring to the research title, more emphasis on sexual violence in the rape category, in the Indonesian Dictionary (1988) is an act of violation by violence. This action is carried out using coercion, threats, bribery, deception and even pressure (Noviana, 2015). uncovering the informative meaning contained in the minds and minds of adolescents who experience sexual violence. The method used qualitatively by the phenomenological approach of Ponty's perception emphasizes unstructured interviews with research subjects who are teenagers victims of sexual violence. Data obtained through interviews or observations will be in the form of words, behavior or documentation all of which are informant of the understanding of each individual victim of sexual violence as well as his life experience and how individuals give meaning to the event.
\end{abstract}

The results showed different meanings of the body to the victims with different family backgrounds (nuclear family). Reflections from Ponty about the meaning of the body between theory and findings were significant. Before the events of sexual violence all victims considered that their bodies were very important and must be maintained. After the event of sexual violence with a different process, each victim interpreted his body to experience a difference.

Keywords: Psychosocial dynamics, child sexual violence, body meaning

(C) 2018 Universitas Muria Kudus 


\section{PENDAHULUAN}

Menurut satu penelitian, lebih dari 24 orang dalam satu menit melaporkan perkosaan atau kekerasan seksual di Amerika Serikat.Pakar dari CDC (Center for Disease Control) menyebutkan bahwa gambaran dari penelitian ini mengejutkan.Pasalnya penelitian ini juga ditemukan bahwa hampir 20\% wanita di Amerika Serikat pernah diperkosa atau mengalami upaya perkosaan. Bahkan temuan CDC juga menyebutkan bahwa lebih dari satu juta perempuan melaporkan bahwa dirinya diperkosa dalam rentang waktu 12 bulan sebelum survey dimulai (BBC News, 2011).

Dilansir dari laman Tirto.id (2018) budaya perkosaan mambuat korban seringkali merasa turut berkontribusi pada kejadian nahas yang menimpanya.Sepanjang tahun 2018 menjadi tahun yang buruk bagi sejumlah perempuan, publik di tanah air disuguhi dengan rangkaian kasus perkosaan dan kekerasan seksual. Mirisnya, kasus-kasus ini tak cukup membangkitkan perlawanan yang masif, dimulai dari kasus WA (15) remaja asal Jambi yang diperkosa oleh kakak kandungnya AA (18) hingga hamil namun ibunya memberikan ramuan jamu tradisional dan memijat perut sang anak. WA justru dijatuhi hukuman enam bulan karena tuduhan tindak aborsi, sedangkan kakaknya AA dihukum dua tahun penjara atas perbuatan perkosaan yang ia lakukan.

Kasus yang juga tak luput dari perhatian adalah kasus Agni, seorang mahasiswi UGM yang mengalami kekerasan seksual oleh rekannya saat melakukan KKN di Pulau Seram, Maluku.la melakukan pelaporan saat satu bulan kejadian telah berlalu, yang sebelumnya ia harus menerima kenyataan bahwa pihak kampusnya menilai bahwa itu tindak pelanggaran ringan. Pelaku tidak bisa dikeluarkan dari kampus, melainkan hanya penundaan kelulusan dan pengulangan KKN. Korban-korban harus menanggung dua kali kemalangan, menjadi korban kekerasan seksual perkosaan sekaligus menjadi korban kriminalisasi dan diskriminasi.

Di Indonesia, manusia yang rawan akan kekerasan seksual adalah wanita. Beragam persoalan kekerasan seksual yang dialami wanita, diantaranya perkosaan, penganiayaan, dan pembunuhan (Sumera, 2013). Rentetan kasus kekerasan seksual khususnya perkosaan telah mengundang ketertarikan untuk diteliti lebih dalam karena memunculkan berbagai dampak baik secara fisik maupun psikologis.

Kasus kekerasan seksual pada anak yang semakin banyak terjadi membuat orang disekitar mereka seperti keluarga harus ekstra melindungi dari pelaku kekerasan seksual. Apabila perilaku demikian tidak dilakukan oleh keluarga akan ada kemungkinan bahwa anak menjadi korban kekerasan seksual. Jika seorang anak sudah menjadi korban dampak yang terjadi pada anak tidak hanya luka pada vagina melainkan terdapat dampak lain yang dapat merusak kehidupan anak, seperti dampak secara emosional yang mengakibatkan timbulnya gangguan secara psikis. Oleh karena itu, akan lebih baik jika keluarga menjaga anak dengan 
baik dan memberikan pengertian kepada anak untuk tidak mudah percaya dengan orang lain yang baru ia kenal, juga memberikan pembelajaran mengenal anggota keluarga (Nurwanti, 2016).

Dampak kekerasan seksual yang terjadi ditandai dengan adanya powerlessness, dimana korban merasa tidak berdaya dan tersiksa ketika mengungkap peristiwa pelecehan seksual tersebut. Gambaran faktor psikososial pada korban kekerasan seksual digambarkan dalam dimensi afeksi, kognisi, psikomotor, dan sosial. Faktor psikososial tersebut seperti kecenderungan emosi negatif seperti perasaan benci dan menyimpan dendam, keinginan untuk menjalani kehidupan bebas, penilaian yang cenderung negatif pada dirinya sendiri dan kehidupan yang dijalani, perilaku seksual yang tidak wajar, serta relasi yang buruk dengan keluarga atau lingkungan sekitarnya (Sakalasastra \& Herdiana, 2012).

Hasil penelitian ini akan memberikan gambaran baru mengenai dinamika psikososial pada remaja korban kekerasan seksual, dimana penelitian terdahulu yang dilakukan oleh Wardhani \& Lestari (2006) memberikan hasil bahwa ketika seseorang mengalami kekerasan seksual maka kejadian tersebut dapat menimbulkan suatu trauma yang sangat mendalam dalam diri seseorang tersebut terutama pada anak dan remaja.

\section{METODE PENELITIAN}

Penelitian ini menggunakan metode kualitatif dengan pendekatan fenomenologi persepsi Ponty menitikberatkan pada wawancara tidak terstruktur.Aspek yang digunakan dalam penelitian ini adalah tubuh, dunia dan tubuh yang mendunia (Ponty, 2005). Kontruksi penelitian adalah untuk mengungkap makna pengalaman rasa yang dialami oleh korban kekerasan seksual. Mulai dari bagaimana seseorang itu sebelum mengalami kekerasan seksual, saat mengalami dan setelah mengalami kekerasan seksual.Masing-masing korbannya memiliki perbedaan makna dalam memandang. Kemampuan yang dimiliki oleh masing-masing subjek berbeda, dikarenakan perbedaan proses dan faktor yang mempengaruhinya.

Data yang diperoleh melalui wawancara ataupun observasi akan berupa kata-kata, perilaku ataupun dokumentasi yang kesemuanya bersifat informantif dari pemahaman masing-masing individu korban kekerasan seksual sebagaimana pengalaman hidupnya dan bagaimana individu memberikan makna pada kejadian tersebut tanpa peneliti memberikan perlakuan tertentu ataupun manipulasi data. Data tersebut kemudian dianalisis secara induktif untuk mendapatkan makna persepsi makna tubuh tentang pengalaman rasa.

Penentuan informan pada penelitian ini dilakukan dengan teknik purposie sampling dimana pemilihan informan dipilih secara sengaja berdasarkan kriteria yang telah ditentukan dan ditetapkan berdasarkan tujuan penelitian. Informan yang dibutuhkan dalam penelitian ini 
adalah remaja putri berusia dibawah 21 tahun (Kartono, 2007) dan pernah mengalami kekerasan seksual spesifik pemerkosaan.

Maka informan dalam penelitian ini adalah :

1. LR usia 18 th Dsn Ngembeh RT/RW 002/007 Ds Ngumpul Jogoroto Jombang

2. AM usia 18 th Dsn Dongdang RT/RW 010/005 Ds Mojodanu Kec Ngusikan Jombang

3. IP usia 16 th Dsn Mlerep Kec Ngusikan Kab Jombang.

\section{HASIL \& PEMBAHASAN}

Berdasar temuan di lapangan terkait dengan dinamika psikososial remaja korban kekerasan seksual sesuai dengan teori Ponty tentang persepsi atau pemaknaan tubuh. Melihat sisi psikologinya dari mentalitas informan seperti rasa takut, gembira atau tertekan yang akan ditunjukkan pada keterkaitan sisi sosialnya dengan cara bagaimana informan berinteraksi dengan saudara, teman atau orang yang ada di sekitarnya.

Informasi pemaknaan tubuh informan pada masa lalu, saat terjadi peristiwa kekerasan dan pasca kekerasan seksual itu terjadi dapat digambarkan temuan yang diklasifikasi pada masing-masing informan berikut ini.

Tabel Hasil Penelitian

\begin{tabular}{|c|c|c|c|}
\hline Korban & $\begin{array}{c}\text { Sebelum Terjadi } \\
\text { Kekerasan Seksual }\end{array}$ & $\begin{array}{c}\text { Psikososial Ketika } \\
\text { Kekerasan Seksual } \\
\text { Terjadi }\end{array}$ & $\begin{array}{c}\text { Psikososial Sesudah } \\
\text { Kekerasan Seksual Terjadi }\end{array}$ \\
\hline LR & $\begin{array}{l}\text { Mempunyai hubungan } \\
\text { yang baik dengan teman, } \\
\text { keluarga dan lingkungan. } \\
\text { Hidup untuk berkarya } \\
\text { dan menyelesaikan } \\
\text { sekolah dengan baik. } \\
\text { Memaknai kondisi } \\
\text { tubuhnya sebagai pribadi } \\
\text { yang sehat kuat dan bisa } \\
\text { melaksanakan kegiatan } \\
\text { dengan baik ditunjang } \\
\text { dengan prestasinya } \\
\text { sebagai atlit voli lokal. }\end{array}$ & $\begin{array}{l}\text { Mempunyai ketakutan baik } \\
\text { untuk masa depannya, } \\
\text { maupun tanggapan } \\
\text { orangtuanya terhadap } \\
\text { kondisinya yang sudah } \\
\text { tidak sempurna lagi. Usaha } \\
\text { untuk menggugurkan } \\
\text { kandungan sebagai wujud } \\
\text { untuk bisa diterima kembali } \\
\text { keluarga meskipun } \\
\text { keluarga } \\
\text { mengetahui } \\
\text { kondisinya. }\end{array}$ & $\begin{array}{l}\text { Keinginan untuk bisa } \\
\text { mendapatkan ijasah melalui } \\
\text { kejar paket kemudian bekerja } \\
\text { dan berusaha bisa merawat } \\
\text { anaknya sendiri setidaknya } \\
\text { berusaha tidak merepotkan } \\
\text { orangtua. Tidak mempunyai rasa } \\
\text { takut lagi dalam melanjutkan } \\
\text { hidup karena dukungan orang } \\
\text { tua dan teman-teman dekatnya. } \\
\text { Masih merasa dihargai jadi tidak } \\
\text { lagi merasakan ketakutan lagi } \\
\text { seperti saat terjadinya peristiwa } \\
\text { kekerasan seksual menimpa diri } \\
\text { LR. Masih mempunyai cita-cita } \\
\text { bisa melanjutkan hidup dengan } \\
\text { baik dan berkeluarga lagi dengan } \\
\text { orang yang lebih baik dan } \\
\text { bertanggungjawab. }\end{array}$ \\
\hline AM & $\begin{array}{l}\text { Hubungan baik dengan } \\
\text { teman meskipun tidak } \\
\text { begitur banyak } \\
\text { mempunyai teman yang } \\
\text { sekedar diajak ngobrol. } \\
\text { Selebihnyar korban } \\
\text { merasa tidak percaya diri } \\
\text { dikarenakan sebagai } \\
\text { anak yang ikut kakak dan } \\
\text { harus r membantu } \\
\text { kakaknyaram } \\
\text { menyelesaikan tugas } \\
\text { rumah tangga. Namun } \\
\text { tidak mengalami }\end{array}$ & $\begin{array}{l}\text { Ketakutan, marah pada diri } \\
\text { sendiri karena tidak mampu } \\
\text { melawan dan pernah ingin } \\
\text { melakukan bunuh diri } \\
\text { namun masih mengingat } \\
\text { bahwa dosa jika melakukan } \\
\text { bunuh diri. }\end{array}$ & $\begin{array}{l}\text { Tidak ada keinginan lagi untuk } \\
\text { berkeluarga, karena jijik melihat } \\
\text { laki-laki. Hanya ingin } \\
\text { melanjutkan hidup demi adik- } \\
\text { adiknya yang ditinggalkan di } \\
\text { rumah kakaknya dan ingin } \\
\text { merawatnya. Berharap bisa } \\
\text { menyelesaikan sekolah (SMA) } \\
\text { kemudian bekerja dan merawat } \\
\text { adiknya. }\end{array}$ \\
\hline
\end{tabular}




\begin{tabular}{|c|c|c|c|}
\hline & $\begin{array}{l}\text { kesulitan ketika } \\
\text { berinteraksi atau } \\
\text { berhubungan dengan } \\
\text { orang lain. Hanya karena } \\
\text { memang tipikal AM tidak } \\
\text { begitu suka bicara yang } \\
\text { tidak penting. }\end{array}$ & & \\
\hline IP & $\begin{array}{l}\text { Mempunyai hubungan } \\
\text { yang baik dengan teman } \\
\text { juga keluarga (nenek) } \\
\text { sebelum dibawa ke } \\
\text { panti. Berinteraksi tanpa } \\
\text { masalah dengan seluruh } \\
\text { penghuni panti dan } \\
\text { seperti keluarga. }\end{array}$ & $\begin{array}{l}\text { Takut dan bingung } \\
\text { menceritakan pada siapa. } \\
\text { Namun tidak ada sampai } \\
\text { pada keinginan bunuh diri } \\
\text { karena takut dosa berlipat. } \\
\text { Pernah sekali ada usaha } \\
\text { menggugurkan kandungan } \\
\text { namun berikutnya sadar itu } \\
\text { juga dosa. }\end{array}$ & $\begin{array}{l}\text { Merasa menjadi pribadi yang } \\
\text { masih jauh dari sempurna } \\
\text { karena melihat ada sosok yang } \\
\text { dijadikan idola. Keinginan untuk } \\
\text { berkeluarga ada tapi setelah } \\
\text { semua keinginannya tercapai } \\
\text { yaitu bekerja dan mengambil } \\
\text { anaknya yang berada di panti. }\end{array}$ \\
\hline
\end{tabular}

\section{KESIMPULAN DAN SARAN}

\section{a. Kesimpulan}

Pada dinamika sosial menunjukkan kesamaan perilaku korban yang ditampilkan bisa segera berinteraksi dengan yang lainnya setelah mendapatkan perlakuan yang baik dari keluarga, teman dan lingkungan sekitarnya. Sesuai dengan fenomenologi persepsi Ponty untuk mendalami dan menguraikan pengalaman dari korban dengan menjauhkan dari segala asumsi pihak luar yang bisa mengganggu dan mengkontaminasi makna sebenarnya dari pengalaman korban.

b. Saran

1. Bagi keluarga, meningkatkan pengawasan dan waspada karena bahaya kekerasan seksual ada dimana-mana. Bekal agama, cara melindungi diridengan baik sebagai upaya untuk menghindari terjadinya kekerasan seksual.

2. Bagi pendamping (pekerja sosial) dinas sosial juga lembaga-lembaga sosialyang bergerak dalam bidang pendampingan perempuan dan anak bisa lebih memperhatikan kebutuhan penyembuhan secarapsikologisnya. Jadi bukan hanya kebutuhan pendampingan secara advokat saja.

\section{DAFTAR PUSTAKA}

Putri, A.W. (2018). 2018 Jadi Tahun yang Buruk Bagi Korban Kekerasan Seksual. Tirto.id. di unduh pada tanggal 10 Januari 2017

Kusuma, Wijaya. (2018). Kasus Dugaan Pelecehan Seksual Mahasiswi UGM Saat KKN: Viral lewat Balairungpress hingga Wisuda Ditunda. Kompas.com di unduh pada tanggal 10 Januari 2017

Kartono, K. (2007). Psikologi Anak. Bandung: Mandar Maju.

KBBI, T. (1988). Kamus Besar Bahasa Indonesia. Jakarta: Balai Pustaka. 
Merleau-Ponty, M.(2005).Phenomenology of Perception, diterjemahkanC. Smith, Routledge, Routledge.

Noviana, I. (2015). Kekerasan Seksual Terhadap Anak: Dampak dan Penanganannya. Sosio Informa, hal 13-28.

Nurwanti, P. (2016). Psikologi Forensik :Dampak Kekerasan Seksual Terhadap Anak. Universitas Brawijaya : Malang.

Sakalasastra \& Herdiana, (2012). Dampak Psikososial Pada Anak Jalanan Korban Pelecehan Seksual Yang Tinggal di Liponsos Anak Surabya.Jurnal Psikologi Kepribadian dan Sosial. Vol. 1, No. 02, Juni 2012.

Sumera, M. (2013).Perbuatan Kekerasan/Pelecehan Seksual Terhadap Perempuan. Lex et Societatis. Vol 1, No 2, April-Juni.

Wardhani, FY \& Lestari,W. (2006). Gangguan Stres Pasca Trauma pada Korban Pelecehan Seksual dan Perkosaan. Pusat Penelitian dan Pengembangan Sistim dan Kebijakan Kesehatan. Surabaya. 